Başvuru Tarihi: 17.11.2017 Received Date: 17.11.2017

Yayına Kabul Tarihi: 05.01.2018 Accepted Date: 05.01.2018

Yayınlanma Tarihi: 29.01.2018 Published Date: 29.01.2018
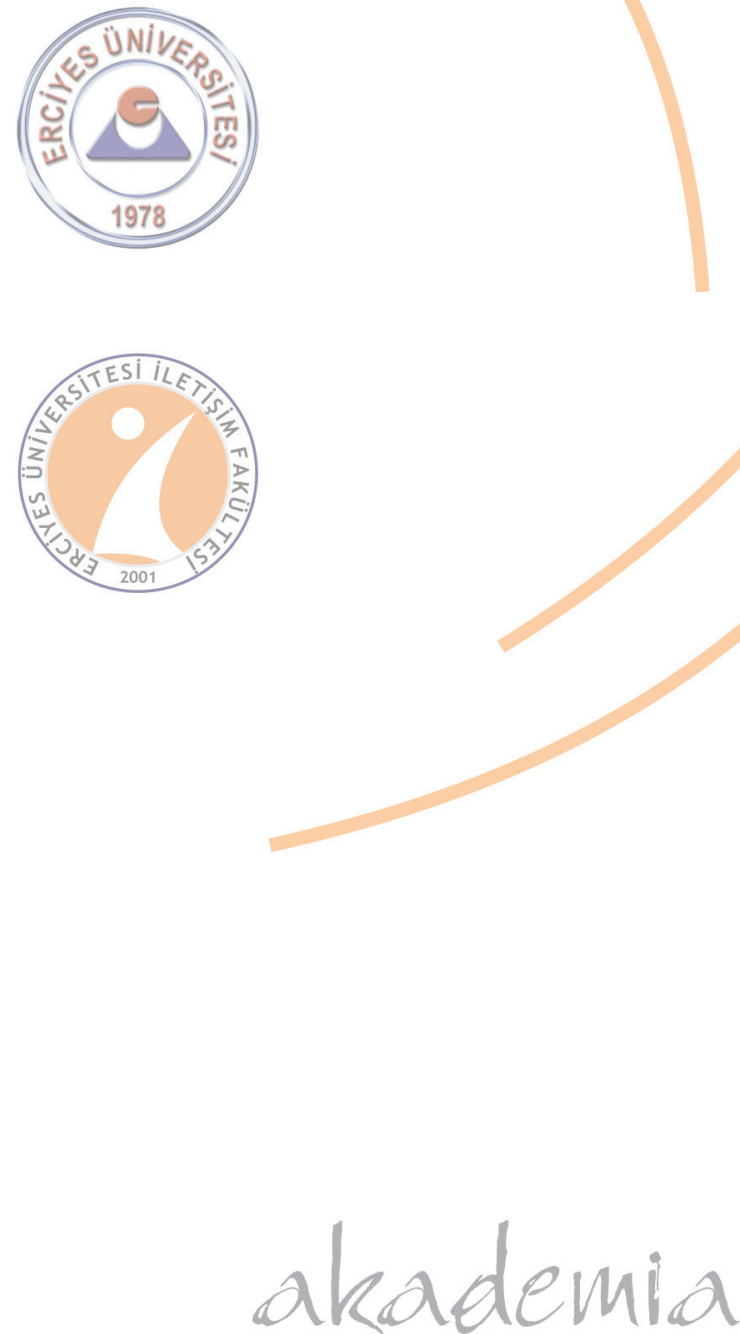
ISSN:1308-3198

Erciyes İletişim Dergisi akademia 2018

Cilt (Volume): 5, Say1 (Number): 3, (276-288)
Burcu Eker AKGÖZ (Doç. Dr.)

Bahçeşehir Üniversitesi İletişim Fakültesi burcu.eker@comm.bau.edu.tr Elif ENGIN (Yrd. Doç. Dr.)

Bahçeşehir Üniversitesi İletişim Fakültesi elif.engin@,comm.bau.edu.tr

\section{KURUMSAL SOSYAL SORUMLULUK ÇERÇEVESINDE ÇEVRESEL VATANDAŞLIK}

\section{$\ddot{\mathbf{O} z}$}

Günümüzde kurumların, hedeflerini gerçekleştirebilmek ve varlıklarını sürdürebilmek için sadece kar odaklı hareket etmeleri mümkün olmamaktadır. Paydaşlarıyla ve içinde yaşadığı toplumla iyi ilişkiler kurması ve devam ettirmesi gerekmektedir. Bu nedenle sadece finansal olarak güçlü değil, aynı zamanda sosyal anlamda da topluma ve paydaşlarına katkısı fazla olan kurumlar itibar görmeye başlamıştır. Toplumsal ihtiyaçları ve beklentileri karşılamak her kurumun felsefesi ve değerleri içerisinde yer almak zorundadır. Bütün bu gelişmeler çerçevesinde kurumlara yeni sorumluluklar yüklenmiş ve sosyal sorumluluk çalışmalarının yanı sıra kurumlardan sorumlu bir vatandaş olmaları beklenmiştir. Özellikle son dönemlerde çevre ve doğa konuları, toplumda gittikçe önem kazanmış ve kurumlardan da bu yönde somut davranışlar ortaya koymaları talep edilmiştir. Kurumsal çevresel vatandaşlık ile çevreyi koruyan ve sahip çıkan şirketlerin sayısı gün geçtikçe artmaya başlamıştır. Bütün bu gelişmeler çerçevesinde, bu çalışmanın amac1, 2017 Fortune 500 Türkiye listesine girmiş ilk 50 şirketin, kurumsal web sitelerinde kurumsal çevre vatandaşlıklarına dair mesajlar iletip iletmediklerini incelemektir. $\mathrm{Bu}$ şirketlerin web sitelerinin incelenmesi üzerinden yapılan çalışmada, kurumların 'çevresel vatandaşlık' çerçevesinde tanımlanan çalışmaları değerlendirilmiş ve web siteleri üzerinden "çevresel vatandaş" mesajı verip vermediği ortaya konmuştur.

Anahtar kelimeler: Kurumsal Sosyal Sorumluk, Kurumsal Vatandaşlik, Çevresel Vatandaşl1k, Web Siteleri.

\section{ENVIRONMENTAL CITIZENSHIP WITHIN THE FRAMEWORK OF CORPORATE SOCIAL RESPONSIBILITY}

\section{Abstract}

Today, for corporations; it is not possible to act only in a profit-oriented manner in order to be able to realize their goals and to sustain their existence. They need to establish and maintain good relations with stakeholders and the society in which they live. For this reason, corporations that are not only financially strong but also contributing to their stakeholders and societies have begun to be respected. Meeting social needs and anticipations has to take place within the philosophy and values of every corporation. Within the framework of all these developments, corporations are expected to have new responsibilities and to be responsible citizens besides their social responsibility activities. Especially in recent times, environmental issues have become increasingly important in the society and it has been demanded from the corporations to present concrete behaviors in this direction. The number of companies that protect the environment with corporate environmental citizenship is increasing day by day,. In the framework of all these developments, the aim of this study is to demonstrate whether the first 50 companies listed on the 2017 Fortune 500 Turkey disseminate messages about corporate environmental citizenship in their corporate web sites. In this study, which is based on the analysis of the websites of these companies, the categories defined within the framework of 'environmental citizenship' were examined and it is revealed that they give the message of "environmental citizen" through their websites.

Keywords: Corporate Social Responsibility, Corporate Citizenship, Corporate Environmental Citizenship, Corporate Websites. 


\section{Giriş}

Enformasyon toplumunun en önemli getirilerinden birisi de iletişim ve teknolojide sınırların ortadan kalkması ve her alanda yaşanan değişim ve gelişimin toplumsal bir farkındalık yaratmasıdır. Neo-liberal ekonomilerin, günümüz rekabet sistemine olan etkisi tartış1ırken, rekabetçi ortamda sadece kurumun mali başarılarından bahsetmek artık söz konusu olmamaktadır. Kurumların, sosyal anlamda başarıları daha fazla konuşulur ve tartışılır hale gelmiştir. Toplumsal ihtiyaçları ve beklentileri karşılamak kar amacı olsun ya da olmasın her kurumun felsefesi ve değerleri içerisinde yer almak zorundadır. Bütün bu gelişmeler, kurumların hedef kitlesiyle olan iletişimini ve ilişkisini farklı bir boyuta taşımıştır. Bu süreç içerisinde, kurumlara yeni sorumluluklar yüklenmiş ve sosyal sorumluluk çalıșmalarının yanı sıra kurumlardan sorumlu bir vatandaş olmaları beklenmiştir.

Bir kurumun bulunduğu bölgede paydaşlarına, çalışanlarına, hissedarlarına, müşterilerine ve tedarikçilerine karşı sorumluluklarını yerine getirdiği uygulamalar bütünü olarak tanımlanan kurumsal vatandaşlık (Logan ve diğerleri, 1997) pek çok sorumluluğu ve zorunluluğu da beraberinde getirmektedir. Finansal, yasal, etik ve sosyal sorumluluklar çerçevesinde görevini tam ve başarıyla yapan kurumlar günümüz iş dünyasının kazananları olmaktadır. Kurumlar bu sorumlulukları çift yönlü simetrik iletişim ile eyleme dönüştürürken aynı zamanda paydaşlarına yaptıkları eylemleri anlatmaları da gerekmektedir. Bunu gerçekleştirmek için de kurumsal web siteleri, görünürlüğü sağlaması, interaktif iletişim ortamı yaratması ve her türlü mesajın kolayca iletilebilme imkanı yaratan bir mecra olması sebebiyle en etkin iletişim aracı olmaktadır.

Enformasyon toplumunun gereklerinden olan teknolojinin, yayılımı ve kullanımı ile birlikte kurumların paydaşlarla iletişimindeki değişim de kaçınılmaz olmuştur. Kurumsal web siteleri, kurumlara kesintisiz erişimi sağlayan, kurumun hem iç hem de dış çevresi ile entegrasyon yaratabilen, görünürlük ve imaj oluşturmada yardımcı olan bir iletişim aracı olması sebebiyle, halkla ilişkiler çalışmaları kapsamında önemli bir taktiksel güç olmaktadır. Web siteleri, kurumlar tarafından belirlenen amaç doğrultusunda düzenlenirken, kurumun tanıtımının yapılması, kurumsal imajın ve itibarın pekiştirilmesi temel amaçlardandır. Kurumun iç ve dış çevresi ile olan iletişiminde ön plana çıkan web siteleri, kurumsal iletişimin gerçekleşmesine imkan sağlayan bir araçtır.

\section{Kurumsal Sosyal Sorumluluk}

Kurumlar; varlıklarını devam ettirebilmek, sorumluluklarını yerine getirebilmek ve hem iç hem de dış çevreleriyle bütünleşmek için sağlıklı bir iletişime ihtiyaç duymaktadırlar. Paydaşlarıyla simetrik, anlayış ve diyaloğa dayalı bir iletişim gerçekleştirmek isteyen kurumlar, sosyal sorumluluk çalışmalarına ağırlık vermektedirler. Kurumsal sosyal sorumluluk kavramı, ilk olarak H. Bowen'ın "Social Responsibilities of the Businessman" kitabında yer almıştır. Kitapta kurumsal sosyal sorumluluk kavramı, toplumun hedefleri ve değerleri açısından istenen politikaları izlemek, uygun kararları almak ya da ilgili faaliyetleri takip etmek için işadamları tarafından üstlenilmesi gereken yükümlülükler $(1953,6)$, olarak tanımlanmıştır. Uygulama alanına baktığımızda ise o dönemde kurumların sosyal sorumluluk kavramını hayata geçirip uyguladıklarını söylemek pek de doğru olmayacaktır. Toplumsal olarak da genel düşünce, kurumlardan ziyade kişilerin veya kar amacı gütmeyen kuruluşların iyi işler yapması ve sosyal sorumlu olması gerektiğiydi. 1970'lere geldiğimizde ise ünlü ekonomist Milton Friedman NY Times'da "The social responsibility of business is to increase its profits" isimli makalesi ile konuya kesin bir yaklaşımda bulunmuş ve bu görüşleri tartışma yaratmıştır. Sosyal sorumluluğa dair şunları söylemektedir (Ersel, http://acikradyo.com.tr/arsiv-icerigi/milton-friedman-vesirketlerin-toplumsal-sorumlulugu);

\footnotetext{
"İşletmenin sorumlulukları olduğunu söylemek ne demektir? Yalnızca insanların sorumlulukları olabilir. O halde şirketin sorumluluğu dediğimizde aslında bazı insanların sorumluluğunu kastediyoruz. "Özgür” piyasa ekonomisi ve özel mülkiyetin olduğu bir sistemde bir şirketin faaliyetlerinden sorumlu olanlar onun yöneticileridir. Bu kişiler,
} 
onları istihdam edenlere (yani şirketin ortaklarına) karşı doğrudan sorumludurlar. Şirket yöneticilerinin sorumluluğu toplumun yasal ve ahlâksal kurallart içinde onlart istihdam edenlere en çok parayı kazandırmaktan ibarettir. Bir şirket yapay bir kişidir ve bu anlamda yapay sorumluluklara sahip olabilir, ancak bir bütün olarak "işletme" nin sorumluluklarl olduğu söylenemez......."

80 'ler ise toplumun, kurumları ve kar elde etme yöntemlerini sorgulamaya başladıkları, etkisi büyük kurumsal krizlerin ortaya çıtığı ve sosyal sorumluluk çalışmalarının öneminin yoğun bir şekilde gündeme geldiği bir dönemdir. Bu dönemlerde kurumsal sosyal sorumluluk kavramının tanımları ve kapsamı üzerine çeşitli çalışmalar yapılmış ve kavram; hem literatürde hem de uygulama alanında yerini sağlamlaştırmıştır. Kurumsal sorumluluk, kurumsal sosyal performans, kurumsal etik ve kurumsal vatandaşlık kavramları da kurumsal sosyal sorumluluk kavramı çerçevesinde ön plana çıkmış bazı durumlarda birbirinin yerine kullanılmıştır. Bu alanda çok fazla çalışma yapanlardan biri de Archie Carroll'dır. Carroll, kurumsal sosyal sorumluluğu ekonomik, yasal, etik ve gönüllü (hayırseverlik) sorumluluklar başlikları altında dört boyutta incelemiştir $(1979,500)$. Ekonomik sorumluluklar, tüketicilerin ihtiyaç duyduğu ve talep ettikleri; mal ve hizmetlerin üretilmesini, bu süreç içerisinde de kabul edilebilir bir kazanç elde etmesini; yasal sorumluluklar, kurumların faaliyetlerini gerçekleştirirken yasa ve yönetmeliklere uymasını, ekonomik görevlerini hukuk çerçevesi içinde yerine getirmelerini; etik sorumluluklar hissedarların, çalışanların, tüketicilerin ve toplumun kurumlardan beklediği ve yasalarda yer almayan standartları, norm ve davranışları; gönüllü sorumluluklar kurumların iyi birer kurumsal vatandaş olmasını ve toplumun beklentilerine cevap veren kurumsal eylemleri kapsamaktadır (Carroll, 1991, 40-43).

Sosyal sorumluluk, bir işletmenin ekonomik ve yasal koşullara, iş ahlakına, işletme içi ve çevresindeki kişi ve kurumların beklentilerine uygun bir çalışma stratejisi ve politikası gütmesine, insanlarl mutlu ve memnun etmesine ilişkindir (Eren, 2000, 99). Bu çerçeveden baktığımızda sosyal sorumluluk kavramı kurumun sadece iş çevresindeki paydaşlarını değil, dış paydaşlarını da gözeterek, sorumlu ve etik davranmasıdır. Kısacası, kurumların içinde bulunduğu topluma karşı sorumlu olmasıdır. Sorumlu davranışın temelini, kurumun kendi çıkarları dışında toplumun varlığını kabul etmesi, temel görevlerin dışında toplumsal sorunlarıyla ilgilenmesi, atacağı adımların doğuracağı sonuçları önceden düşünmesi oluşturmaktadır (Peltekoğlu, 2014, 188). Sosyal sorumluluk kurumun tüm çalışanları, ortakları, müşterileri gibi tüm paydaşlarının istek ve çıarlarını göz önünde bulundurarak, kurumun faaliyetlerine yön verme çabasıdır. $\mathrm{Bu}$ sorumluluklar etik ve ilkeli davranmaktan, çevreyi korumaktan, kurumun ve toplumun çıkarlarını korumaya kadar çok geniş bir yelpazede karşımıza çıkmaktadır.

Kurumsal sosyal sorumluluk, belirli sınıflandırmalardan bağımsız olarak, yöneticilerin kamu politikasını ve sosyal konuları nasıl ele alması gerektiği ile ilgili her türlü kavram olarak da değerlendirilmektedir (Windsor, 2006, 95). Güven inşa etmenin bir yolu olarak da görülen kurumsal sosyal sorumluluk, sadece yaşadığımız fiziki çevre ve onun sorunlarına yönelik çalışmalardan değil, dünyanın herhangi bir yerinde yaşanan ve toplumu ilgilendiren her türlü soruna karşı kurumların sergilemesi gerektiği ‘duruş’ olarak görülmektedir.

Kurumsal sosyal sorumluluğu benimseyen kurumlar, uluslararası International Business Leaders Forum (IBLF) sözleriyle "insanların yaşam kalitesini iyileştirmeye yardımcı olmak için değişim olumlu bir güçtür". Başka bir deyişle, bu tür organizasyonlar iyi kurumsal vatandaşlardır. IBLF'ye göre, kurumsal sosyal sorumluluk, birçok alanda yüksek standartlar için çaba göstermektedir. Bu alanlar şöyledir (Guth ve Marsh, 2006, 180):

1. İnsan hakları, işgücü ve güvenlik

2. İşletmeler ve ekonomik kalkınma

3. İş standartları ve kurumsal yönetim

4. Sağlık promosyonları 
5. Eğitim ve liderlik gelişimi

6. İnsanların yarattığı felaketin hafifletilmesi ve

7. Çevre

Bir kurumun toplumda kabul görmesinin devamlılığının sağlanması, sadece toplumun sorunlarının farkına varmasıyla değil, bu sorunlar hakkında bir şeyler yapmasına bağlıdır. Kurumsal sosyal sorumluluk programları, sorun çözücü olmalı, kurumlar birkaç ulusal sorunu ele alarak bu sorunların çözülmesi yönünde çaba sarf etmelidir (Okay ve Okay, 2005, 490).

\section{Kurumsal Vatandaşlık ve Kurumsal Çevresel Vatandaşlık}

Kurumları yaşadıkları çevreden bağımsız düşünmemiz imkansızdır. Kurumlar, sınırlı kaynakları doğru kullanarak ve koruyarak, sosyal sorumluluk bilincini geliştirerek ve çevreye karşı duyarlı olarak topluma karşı olan sorumluklarını yerine getirmektedirler. Sosyal sorumluluk duruşunun en önemli göstergesi, 'iyi kurumsal vatandaş' olmaktır. Bu nedenle; kurumsal sosyal sorumluluk kavramı, kurumsal vatandaşlık kavramı ile beraber kullanılmakta ve birbirinden ayrı düşünülememektedir. Kurumsal sosyal sorumluluğa dair yapılan her çalışma, kurumların hedef kitle nezdinde 'iyi birer kurumsal vatandaş' olmalarını sağlamaktadır.

Sosyal sorumluluk kavramından da önce var olan hayırseverlik çalışmaları, bağışlar, hibeler, ihtiyacı olanlara nakit veya ayni yardım, burslar vb. şekillerle uygulanmıştır. $\mathrm{Bu}$ uygulamalar, hem kurum bazında hem de kişi bazında iyi bir vatandaş algısı oluşmasını da sağlamıştır. Böylelikle kurumsal vatandaşlık, iş dünyasının sosyal rolü ile ilgilenen yönetim literatüründe belirgin bir terim olarak ortaya çıkmıştır. Kurumsal vatandaşlık terminolojisi uzun yıllardır var olan, 1980'li yıllardan önce de kullanılan, esasen son yirmi yılda büyük bir artışına tanıklık ettiğimiz bir kavramdır (Crane ve diğerleri, Ed: Scherer ve Palazzo, 2008, 25). Archie Carroll, "Kurumsal Vatandaşlığın Dört Yüzü" isimli çalışmasında, bu kavramın sıklıkla kullanılmasının ve popüler hale gelmesinin sebebinin, 1996 yılında, Başkan Clinton'ın bir grup lider iş adamını toplayarak kurumsal sosyal sorumluluk ve kurumsal vatandaşlık kavramlarını tartıştığı toplantı olduğunu söylemektedir. Başkan Clinton bu toplantıda kurumlara, hissedarları için para kazanırlarken, aynı zamanda çalışanlarıyla beraber toplum için iyi işler yapmaları gerektiğini vurgulamıştır (Carroll, 1998, 1).

Logan, Roy ve Regelbrugge (1997) kurumsal vatandaşlı̆g 1şöyle tanımlamaktadır: Bir kurumun bulunduğu bölgede paydaşlarına, çalışanlarına, hissedarlarına, müşterilerine ve tedarikçilerine karşı sorumluluklarını yerine getirdiği uygulamalardır. İyi bir kurumsal vatandaş olmak için kurumların 4 tip aktivitede bulunmaları gerekmektedir. Bunlar;

1. Kendi ticari çıkarları: Tüm kanun ve yönetmeliklere uymak, paydaşlara fayda sağlayan ve piyasadaki kârlılık ve rekabet gücüne doğrudan katkı sağlayacak aktiviteleri seçmek

2. Anında fayda sağlayacak çıkarları genişletmek: Paydaşlara ve topluluklara fayda sağlayacak normal iş faaliyetlerine dair konuların ötesine geçen, kısa ve orta vadede ölçülebilir fayda sağlamak

3. Uzun vadeli faydalar ile kendi çıkarlarını genişletme: Kurumun başarısını sürdürmede etkili olan eğitim ve öğretim gibi topluluk aktivitelerini desteklemek

4. Ortak 'iyiyi' desteklemek: Destekledikleri ya da katıldıkları toplumsal aktivitelerde, topluluğun ya da paydaşların kurumdan doğrudan fayda sağlayacak beklenti içinde olmamalarıdır.

Kurumsal vatandaşlık genellikle, stratejik iş kriterlerine göre seçilen kurumların hayırseverlik ve iş dünyası ile toplumsal ortaklık faaliyetlerini sürdürdüğü aktivitelerdir (Rondinelli, ve Berry, 2000, 73-74). Kurumsal vatandaşlık; sosyal katılım ve sosyal sorumlulukla beraber bir bütünü oluşturmaktadır. Kurumlar, içinde bulundukları topluma karşı olan sorumluluklarının bilincinde olduğu sürece, hem topluma hem de çevrelerine karşı 'kurumsal 
vatandaşlık' görevlerini de yerine getirmiş olacaklardır. 1990'ların ikinci yarısından itibaren, birçok firma sadece zorunluluktan değil aynı zamanda gönüllü olarak, çevresel düzenlemeler kadar artan çevresel tercihler ve baskılara da karş1lı verebilmek için çevre yönetimini çevresel performanslarını artırmak için uygulamışlardır (Nishitani ve diğerleri, 2017, 10). Toplumun çoğu, çevresel kurumların ve liderlik şirketlerinin kurumsal çevresel sorumluluğunu, kurumun icraatlarının, ürünlerinin ve tesislerinin; atıkları ve emisyonları bertaraf etmek, kaynaklarının etkinliğini ve verimliliğini en üst düzeye çıkarmak, gelecek nesiller tarafindan ülke kaynaklarını olumsuz yönde etkileyebilecek ve ülkenin saadetini bozabilecek uygulamaları, en aza indirgemek olarak tanımlamaktadırlar (Mazurkiewics, 2004, akt, Nayyar ve Sharma, 2006, 4).

Çevresel performans raporları ve dış gözlemciler tarafindan yapılan çalışmalar incelendiğinde, çok uluslu şirketlerin karmaşık bir yapısının olduğunu görülmektedir. $\mathrm{Bu}$ karmaşık yapının da şirketleri 'iyi kurumsal vatandaş' olma çerçevesinde uygulamalar yapmaya doğru ittiği ortaya konmaktadır. Business for Social Responsibility’e göre (1998), yönetmeliklerin uygulanması ile yatırımcıların, düzenleyicilerin ve çıkar gruplarının kamuyu aydınlatmalarına yönelik oluşan kamusal talepler, kurumların kendi sosyal sorumluluklarına yönelik hassasiyetlerinin artmasında önemli bir rol oynamıştır (Rondinelli ve Berry, 2000, 74). Gelişmekte olan kurumsal vatandaşlık uygulamaları, hem işletmelere hem de faaliyet gösterdikleri topluluklara fayda sağlayan işbirliği ve ortaklıklar yoluyla, çevre sorunlarının çözümünde ve önlenmesinde yeni ve etkili yollar sunmaktadır. Bazı şirketler, yerel çevre koşullarının kalitesini ve yerel çevresel sürdürülebilirliği değerlendirmekte, çevreyle ilgili konularda öğretmenler için eğitim ve öğretim programlarını desteklemekte, topluluk tarafından başlatılan çevresel girişimler için fon sağlamakta, çevresel çıkar grupları, kar amacı gütmeyen kuruluşlar ve yerel hükümetlerle çevresel altyapının geliştirilmesi veya iyileştirilmesine katkıda bulunmakta, önemli çevre sorunlarını önlemek veya çözmek için resmi paydaş ilişkileri oluşturmaktadır (Rondinelli ve Berry, 2000, 71).

Banerjee (2002, akt, Chin ve diğerleri, 2017, 301) ise kurumsal çevre vatandaşlığını, kurumların üç çevresel faaliyet çerçevesinde çevreye ve paydaşlarına taahhüdü olarak tanımlamaktadır. İlki, kurumdaki çevre faaliyetlerini meşrulaştırmaktır. İkincisi, kurum stratejisinin oluşturulmasına dahil ederek, biyofizik çevrenin önemini tanımaktır. Üçüncüsü ise çevre konularını şirketin stratejik planlama sürecine dahil etmektir.

Özen ve Küskü’nün $(2009,299)$ farklı çalışmalardan derledikleri “Kurumsal Çevre Vatandaşlığı Boyutları" konuyu anlamamız açısından önemli bir tanımlamadır.

Tablo 1. Kurumsal Çevresel Vatandaşlık Boyutları

\begin{tabular}{|c|c|c|}
\hline \multirow{11}{*}{ Düzenleyici } & \multicolumn{2}{|c|}{ İç organizasyon sistemleri / süreçleri } \\
\hline & \multirow{6}{*}{$\begin{array}{l}\text { Teknolojik } \\
\text { önlemler }\end{array}$} & Atık arıtma teknolojisi \\
\hline & & Atık bertaraf etme politikası \\
\hline & & Atıkların azaltılması politikası \\
\hline & & Atıkların geri dönüş politikası \\
\hline & & Kaynakların kullanımını sınırlama \\
\hline & & Enerji tasarruf politikası \\
\hline & \multirow{4}{*}{$\begin{array}{l}\text { Yapısal } \\
\text { önlemler }\end{array}$} & Çevre faaliyetlerinden sorumlu idari birim \\
\hline & & Çevresel faaliyetlerde çalışanların katılımı \\
\hline & & Çevre yönetim sistemi (örn. ISO 14001) \\
\hline & & Çevresel faaliyetler hakkında çalışanların hizmet içi eğitimi \\
\hline
\end{tabular}




\begin{tabular}{|c|c|c|}
\hline \multirow{9}{*}{ Normatif } & \multirow{3}{*}{ Stratejik önlemler } & Çevre politikası \\
\hline & & Çevre konularında bütçenin tahsisi \\
\hline & & Gelecekteki çevresel planlar \\
\hline & \multirow{4}{*}{$\begin{array}{l}\text { Dış ilişkiler } \\
\text { faaliyetleri }\end{array}$} & Çevreyle ilgili hayır faaliyetleri \\
\hline & & Müşterilerin çevresel duyarlılığını arttırmak \\
\hline & & Pazarlama politikasında çevresel güçlerin kullanılması \\
\hline & & Kurumsal meşruiyetin bir parçası olarak çevrecilik \\
\hline & \multirow{2}{*}{$\begin{array}{l}\text { Üst yönetimin } \\
\text { çevresel } \\
\text { vatandaşlık } \\
\text { faaliyetlerine } \\
\text { yönelik tutumları }\end{array}$} & Çevre faaliyetlerine yönetsel destek \\
\hline & & Çevresel konuların genel algısı \\
\hline Kavramsal & $\begin{array}{l}\text { Çevre } \\
\text { masraflarının } \\
\text { değerlendirilmesi }\end{array}$ & \\
\hline
\end{tabular}

Burada tanımlanan boyutlarla beraber, kurumsal çevresel vatandaşlığının da geniş bir çerçevesi çizilmiştir. Yapılan araştırmalar, ortaya konulan tanımlamalar ve kurumsal davranışlarla çerçevesi belirlenen kurumsal çevresel vatandaşlığı, kurumların toplumsal boyutta sorumlu vatandaş algısını da pekiştirmekte ve güçlendirmektedir. Jun Yu, Kevin R. Coulson, Joyce X. Zhou, H. Joseph Wen ve Qiang Zhao, 'Kurumsal Çevresel Vatandaşlığı' araştırdıkları çalışmalarında, kurumların çevresel vatandaşlığını, 12 kategori üzerinden değerlendirmişlerdir. $\mathrm{Bu}$ kategoriler şöyledir:

Tablo 2. Çevresel Konular*

\begin{tabular}{|l|l|l|}
\hline 1 & Enerji verimliliği & Enerji kullanımında daha fazla verim elde etmeye çalışmak. \\
\hline 2 & $\begin{array}{l}\text { Çevresel etkilerin en aza } \\
\text { indirgenmesi }\end{array}$ & Zararlı çevresel etkilerin azaltılması. \\
\hline 3 & Temiz ve yeşil enerji kaynakları & $\begin{array}{l}\text { Daha temiz, daha az kirleten ya da hiç kirletmeyen enerji } \\
\text { kaynaklarının kullanımı. }\end{array}$ \\
\hline 4 & $\begin{array}{l}\text { Kyoto protokolü / Sera } \\
\text { emisyonları }\end{array}$ & $\begin{array}{l}\text { Kyoto protokolüne uyma ve sera gazı emisyonlarının } \\
\text { azaltılması. }\end{array}$ \\
\hline 5 & Yasal uygunluk & Yasa ve yönetmeliklere uymak. \\
\hline 6 & $\begin{array}{l}\text { ISO 14000 / Çevre yönetim } \\
\text { sistemleri }\end{array}$ & $\begin{array}{l}\text { ISO14000 standartlarına ulaşma veya çevresel yönetim } \\
\text { sistemlerini benimsemek. }\end{array}$ \\
\hline 7 & Koruma & $\begin{array}{l}\text { Toprak, su ve vahşi hayat dahil olmak üzere doğal kaynakları } \\
\text { korumak. }\end{array}$ \\
\hline 8 & Geri dönüşüm / Atık azaltma & Kullanılmış ürünleri geri dönüşüme sokma ve atıkları azaltma. \\
\hline 9 & Çevre eğitimi & Çevre konularında halkı eğitmek. \\
\hline 10 & Enerji Tasarrufu & Daha az enerji kaynağı kullanarak, süreçte tasarruf etmek. \\
\hline 11 & $\begin{array}{l}\text { Enerji talebinin yönetimi/ } \\
\text { Eksiklikler }\end{array}$ & $\begin{array}{l}\text { Enerji sağlanmasında aksamayı en aza indirgemek için } \\
\text { yapılandırılmış prosedürleri kullanmak. }\end{array}$ \\
\hline 12 & Çevre ödülleri & Geçmişteki çevresel çabaları için ödül almış olmak. \\
\hline $\begin{array}{l}* J u n \\
\text { Environmental Citizenship: An Examination of Fortune 500 Web Sites Journal of Internet Commerce, 10:193- } \\
207, \text { 2011, 198. }\end{array}$ & \begin{tabular}{l} 
Zhou, H. Joseph Wen, and Qiang Zhao, Communicating Corporate \\
\hline
\end{tabular}
\end{tabular}

Bu tabloda yer alan 12 madde, kurumların çevre vatandaşlığının anlaşılır hale gelmesi açısından önemlidir. Kurumlar iyi birer kurumsal vatandaş olurlarken, aynı zamanda da toplumsal 
hassasiyet konularından biri olan çevreye daha fazla önem vererek, iyi vatandaş kimliğinin çevre vatandaşlığı kısmını ön plana çıkarmaktadırlar.

\section{Kurumsal Çevresel Vatandaşlık için Kurumsal Web Siteleri}

Dünyanın dört bir yanındaki veri tabanlarını ve bilgisayarları birbirine bağlayan bilgisayar ağı olarak tanımlanan internetin, kısa sürede gelişmesi ve interaktif bir iletişim sağlaması nedeni ile hayatımıza kolayca girmiş ve milyonlara ulaşmıştır. İnternetin web1.0 olarak iletişim sağlamaya başladığı zamandan bu yana teknolojinin hızla gelişmesi ile birlikte internetin kullanım alanlarının genişlemesine bağlı olarak; internetin ilk yıllarından itibaren var olan iletişim araçlarından biri de web siteleri olmuştur. Web 1.0 daha sonra 2.0 ve en son teknolojik gelişmelere adapte olan, kurumlar, markalar ve kuruluşlar için halen önemli bir araç olan web siteleri hedef kitlelerin bilgi aradıklarında karşılarına ilk çıkacak olan iletişim aracıdır (Engin ve Eker Akgöz, 2016, 92).

World wide web'in, 1994'ten sonra popüler anlamda ticari kullanıma girmesiyle kurumlar bu muazzam teknolojik devrimin dişında kalmamak için web sitelerini oluşturmaya ve bu yeni sisteme ayak uydurmaya başlamışlardır. İnternetin kurumlara sağladığı en büyük avantajlardan biri olan web siteleri, kurumlar ve hedef kitleleri arasındaki mesafeyi azaltan iletişim araçlarının başında gelmektedir. Kurumlara ait web siteleri, kendileri hakkında bilgi verme, ürün ve hizmetlerini tanıtma işlevlerinin yanı sıra topluma karşı olan sorumluluklarını da yerine getirdiklerini gösterme imkanı buldukları alanlardır.

İçinde bulundukları sosyal çevrede kurumlar, faaliyet alanlarını ve çabalarını duyurabilmek için web sitelerini kullanmaktadırlar. Web sitelerinin önemini Peltekoğlu $(2014,312)$ şöyle ifade etmektedir: "Her şeyden önce web siteleriyle interaktif iletişimin oluşturulması, yatırımcılar, çalışanlar ve diğer hedef kitlelere katılım ve tartışma zemini yaratır. Elektronik medya aracılığıyla gerçekleştirilen interaktif iletişim, halkla ilişkiler dünyasına sadece hedef kitleye erişme imkanı değil, aynı zamanda hedef kitleyle diyalog imkanı da sunmaktadır." Young, kurumların, web sitelerini sağladıkları katkıları toplum önüne getirmek ve yaptıkları diğer toplumsal işleri görünür hale getirmek için kullandıklarını söylemektedir. Her bir paydaşın farklı amaçlar için kurumsal web siteleri ziyaret ettiğini, kurumların da bu amaçlar doğrultusunda istenilen bilgileri sağlaması gerektiğini belirtmektedir. Böylelikle kurumsal web siteler hem iş hedeflerini gerçekleştirmek için hem de farklı hedef kitlelerin bilgi ihtiyaçlarını karşılamak için önemli bir araçtır (Young, 2001,18). Kurumsal iletişim çalışmalarının vazgeçilmez bir parçası olan web siteleri tanıtım ve pazarlama işlevlerini yerine getirmesinin yanı sıra etkili bir halkla ilişkiler aracıdır. Kurumların web sitelerinin kullanım yerleri şöyle sıralanmaktadır (Okay ve Okay, 2005, 511):

- Medya kuruluşlarına bilgi sağlamak

- Tüm hedef gruplarla günü gününe iletişim kurmak

- Farklı hedef gruplar hakkında bilgi toplamak

- Kurum imajını geliştirmek

- Kurum kimliğini güçlendirmek

- Çalışanlarla iletişimi sağlamak

- Bir kuruluş için statü sembol oluşturmak

- Online satış yapmak

- Uluslararası pazarlara ulaşmak

- İnternette gezen bir kişiye ulaşmak

- Diğer halkla ilişkiler fonksiyonlarını yerine getirmek. 
Çevre konusunda duyarlı olan ve her geçen gün bilinçlenen toplum karşısında şirketler, çevreye verdiği zararı en aza indirgemeye çalışmakta ve telafi edebilmenin yollarını aramaktadırlar. Bu faaliyet ve çabalarını en iyi duyurabilecekleri mecra internet ve kurumların kendi web siteleridir. Şirketler hedef kitlelerine; sosyal sorumluk ve çevre hakkındaki faaliyetlerini buradan duyurma imkanı bulmaktadırlar. Kurumlar için web siteleri, çevreyi koruyan, önem veren ve çevre için bir şeyler yapan kurum imajını oluşturmak, geliştirmek, bu çerçevede kurum kimliğini güçlendirmek ve buna dair paydaşlarına bilgi iletmek için çok önemli iletişim aracıdır. Kurumsal çevresel vatandaşlıkla ilgili davranışlarını ve çalışmalarını web sitelerinden paylaşarak ve bununla ilgili paydaşlardan geribildirim alarak çevre ile ilgili konumlandırma, imaj ve kimliklerini güçlendirmektedirler.

Badarocco (1998), kurumlarla ilgili bilgilere erişimin gittikçe artması ve bilgilerin şeffaf hale gelmesinin kurumların kurumsal sosyal sorumluluk uygulamalarını teşvik edip arttırabileceğini önermiştir. Fortune 500 şirketleri üzerine yapılan bir anket çalışmasında, şirketlerin \% 90'1nın web sitelerinin olduğu ve bu sitelerin de \% 82'sinin en az bir kurumsal sosyal sorumluluk konusunu ele aldığı ortaya konmuştur (Gower ve Cho, 2001, 81). Gelişen teknoloji kurumlara web üzerinden katılımcılığ 1 sağlarken aynı zamanda kurumsa çevresel vatandaşlık davranışlarına dair tüm bilgileri paydaşlarına iletebildikleri bir iletişim aracı olmuştur.

\section{Yöntem}

Çalışmanın amac1, 2017 Fortune 500 Türkiye listesine girmiş ilk 50 şirketin kurumsal web sitelerinde kurumsal çevre vatandaşlıklarına dair mesajlar iletip iletmediklerini ortaya koymaktır. Araştırmada, Jun Yu, Kevin R. Coulson, Joyce X. Zhou, H. Joseph Wen ve Qiang Zhao (2011, 198), çevresel vatandaşlığı belirlemek üzere tanımladıkları 12 kategori ele alınmıştır. Bu kategoriler, enerji verimliliği, çevresel etkilerin en aza indirgenmesi, temiz ve yeşil enerji kaynakları, Kyoto protokolü/sera emisyonları, yasal uygunluk, ISO14000/çevre yönetim sistemleri, koruma, geri dönüşüm /atık azaltma, çevre eğitimi, enerji tasarrufu, enerji talebinin yönetimi/eksiklikler ve çevre ödülleridir.

Araştırmanın evreni Fortune 500'de yer alan şirketlerden oluşmakta, örneklemi ise Fortune 2017 yılında yer alan ilk 50 kurum olarak belirlenmiştir. Araştırmanın sinırlılıkları, Jun Yu ve diğerlerinin çevresel konular ile ilgili kategorileri çerçevesinde ele alınmış ve bu kategorilerin web sitelerinde olup/olmaması üzerinden belirlenmiştir. Bahsedilen kategoriler dişındaki diğer çevresel konular ele alınmamıştır.

Çalışmanın araştırma soruları şöyledir:

- Fortune 500 Türkiye listesine girmiş ilk 50 şirketin kurumsal web sitelerinde çevresel vatandaşlık konuları yer almakta mıdır?

- Çevresel vatandaşl1k konularında en çok ve en az yer alan kategoriler hangileridir?

$\mathrm{Bu}$ kurumların web sitelerinin tanımlanan kategorilere göre analizinde, iki kodlayıcı kullanılmıştır. Kodlayıcılar; 12 başlıktan oluşan çevresel vatandaşlık kategorileri için hazırlanan kodlama formunda, bu başlıkların olup olmadığını araştırmışlardır. Kodlayıcıların objektifliğini arttırmak için onlara, çevresel vatandaşlık konusu ve her bir kategorinin içeriği hakkında bilgi verilmiştir. Kodlayıcıların kısa eğitiminden sonra, kodlama formu için pre-test uygulanmıştır. Pilot çalışmanın sonuçlarına göre gerekli iyileştirmeler yapılmıştır. Bu düzenlemeden sonra, araştırmacılara kodlayıcı formları dağıtılmış ve araştırma tamamlanmıştır. Böylece kurumların web siteleri tanımlanan kategorilere göre değerlendirilerek çalışmanın tamamlanması sağlanmıştır.

Pallant'a göre $(2007,220)$, 0.5 Kappa değeri makul anlaşma değerini, 0.7'nin üzeri iyi anlaşma değerini ve 0.8 üzerinin ise çok iyi anlaşma değeri olduğunu göstermektedir. Bu çalışmada kodlayıcılar arasındaki anlaşma düzeyinin ortalaması 0,89'dur. Bu doğrultuda, çok iyi düzeyde anlaşma değeri olduğu bulunmuştur. 


\section{Bulgular}

Kurumların çevresel vatandaşlığının analiz edildiği çalışmada tüm kurumların kendilerine ait web sitesi olduğu görülmektedir. Kategorilerin bulunması ve kodlanması aşamasında, kurumların sadece ana sayfaları baz alınmamıștır. Web sitesindeki tüm ara başlıklar, linkler ve site içi arama motorlarında da kategorilerin taraması yapılmıştır. Tabloda yer alan, kategori başlıkları içinde yer almayan ancak web sitelerinde görülen IS0 14001 Çevre Yönetim Sistemi, ISO 50001 Enerji Yönetim Sistemi bilgileri gibi konular da, içeriği uygun olan kategoriler altında değerlendirilmiştir.

Yapılan araştırma doğrultusunda Fortune Türkiye'de 2017 yılında, ilk 50'de yer alan kurumların çevresel kategorilere dair mesajlarının, SPSS frekans analizi ve yüzdelik dağılımı şöyledir:

Tablo 3. Frekans analizi ve yüzdelik dağıllımı

\begin{tabular}{|c|c|c|c|c|}
\hline & Çevresel Konular & & $f$ & $\%$ \\
\hline \multirow{2}{*}{1} & \multirow{2}{*}{ Enerji verimliliği } & Var & 27 & 54,0 \\
\hline & & Yok & 23 & 46,0 \\
\hline \multirow{2}{*}{2} & \multirow{2}{*}{ Çevresel etkilerin en aza indirgenmesi } & Var & 27 & 54,0 \\
\hline & & Yok & 23 & 46,0 \\
\hline \multirow{2}{*}{3} & \multirow{2}{*}{ Temiz ve yeşil enerji kaynakları } & Var & 18 & 36,0 \\
\hline & & Yok & 32 & 64,0 \\
\hline \multirow{2}{*}{4} & \multirow{2}{*}{ Kyoto protokolü / Sera emisyonları } & Var & 21 & 42,0 \\
\hline & & Yok & 29 & 58,0 \\
\hline \multirow{2}{*}{5} & \multirow{2}{*}{ Yasal uygunluk } & Var & 28 & 56,0 \\
\hline & & Yok & 22 & 44,0 \\
\hline \multirow{2}{*}{6} & \multirow{2}{*}{ ISO 14000 / Çevre yönetim sistemleri } & Var & 27 & 54,0 \\
\hline & & Yok & 23 & 46,0 \\
\hline \multirow{2}{*}{7} & \multirow{2}{*}{ Koruma } & Var & 27 & 54,0 \\
\hline & & Yok & 23 & 46,0 \\
\hline \multirow{2}{*}{8} & \multirow{2}{*}{ Geri dönüşüm / Atık azaltma } & Var & 24 & 48,0 \\
\hline & & Yok & 26 & 52,0 \\
\hline \multirow{2}{*}{9} & \multirow{2}{*}{ Çevre eğitimi } & Var & 24 & 48,0 \\
\hline & & Yok & 26 & 52,0 \\
\hline \multirow{2}{*}{10} & \multirow{2}{*}{ Enerji tasarrufu } & Var & 21 & 42,0 \\
\hline & & Yok & 29 & 58,0 \\
\hline \multirow{2}{*}{11} & \multirow{2}{*}{ Enerji talebinin yönetimi/ Eksiklikler } & Var & 16 & 32,0 \\
\hline & & Yok & 34 & 68,0 \\
\hline \multirow{2}{*}{12} & \multirow{2}{*}{ Çevre ödülleri } & Var & 16 & 32,0 \\
\hline & & Yok & 34 & 68,0 \\
\hline
\end{tabular}

En yükssek değerler; enerji verimliliği, çevresel etkilerin en aza indirgenmesi ve ISO 14000/çevre yönetim sistemleri kategorilerinde ortaya çıkmıştır. Kurumların web sitelerinde çevresel vatandaşlığa dair en az görülen konular ise enerji talebinin yönetimi/eksiklikler, çevre ödülleri, temiz ve yeşil enerji kaynakları'dır.

Bahsedilen kategoriler, çevre konularının kurumsal web sitelerinde yer alması ya da yer almaması üzerinden değerlendirilmiştir. Kategorilerinolmaması, kurumların çevresel vatandaşlığa dair konuların olmadığına değil, web sitesinde yer almadığına dair bilgi sağlamaktadır.

Web siteleri incelendiğinde kurumların çevreye dair projeler yaptıkları ya da var olan projelere destek verdikleri görülmüştür. Örneğin; kurumlar 5 Haziran Dünya Çevre Günü’ne dair etkinlik 
yapmakta, kıyısal alanlarındaki kirliliğin tespiti ve değişikliklerin izlenmesini amaçlayan projelere katılmakta, enerji tasarrufu konusunda farkındalık yaratmak için çocuklara yönelik projelere ağırlık vermekte, doğal yaşamı destekleme projelerinin içinde yer almakta, küresel medya markalarıyla ve kurumlarıyla; kamu, iş dünyası, üniversite ve sivil toplum kuruluşlarından önde gelen uzmanlarının enerjinin geleceğinin tartışıldığı etkinlikler ve online forumlar düzenlemektedirler.

\section{Sonuç}

Sınırlı kaynakların sınırsız bir şekilde tüketildiği günümüz dünyasında, bireyler üzerine düşenleri yerine getirmeye çalışırken, kurumlardan da aynı özveriyi beklemektedirler. Onlarca yıldır çevreye verdikleri zararlar nedeniyle sürekli eleştirilen şirketler, günümüz enformasyon dünyasında tepkilere kayıtsız kalamamakta, kalanlar ise bedelini ağır şekilde ödemektedirler. Bu nedenle kurumlar da çevreye verdikleri zararı en az indirgeme ve bu konuda yapılan çalışmaların parçası olma yolunda ilerlemektedirler. Kurumsal sosyal sorumluluk çalışmalarının öneminin ortaya konduğu günümüz dünyasında sosyal sorumluluğun bileşenlerinden olan kurumsal vatandaşlık kavramı da sıklıkla karşımıza çıkmaya ve hatta sosyal sorumluluk kavramıyla eşdeğer tutulmaya başlanmıştır. Kurumsal vatandaşlık kavramı çerçevesinde kurumlar, iyi birer vatandaş olmanın gereklerini yerine getirerek, ekonomik, yasal, etik ve hayırseverlik alanlarında sorumluluklarını gerçekleştirmektedirler. Bütün bunların arasında çevre bütün konuların önüne çıkmaktadır. Bunun en önemli nedeni daha önce de bahsettiğimiz gibi artık doğal kaynakların sınırlı sayıda olduğunu bilmemiz ve bilimsel verilerle bunun ortaya konmasıdır. Bu nedenle kurumlar, iyi birer vatandaş olurken aynı zamanda kurumsal çevresel vatandaşlık özelliklerine de ağırlık vermeye başlamışlardır.

Kurumlar; itibarlarını artırmak, kurum imajını ve konumlandırmalarını güçlendirmek için yaptıkları faaliyetlerin iletişimine önem vermektedirler. Kurumsal çevresel vatandaşlık da bunlardan biridir. Kurumlar tutum ve davranışlarıyla, çevreye verdikleri önemi ve bu konuda nasıl iyi bir vatandaş olduklarını ortaya koyarlarken, bunun iletişimini paydaşlarıyla gerçekleştirmek için de pek çok iletişim araçlarından faydalanırlar. Kurumsal web siteleri de bunlardan birisidir. Paydaşlarla etkileşimi sağlayan, kurumsal bilgilerin iletilmesini kolaylaştıran, mesajın direk ulaşmasında etkili bir araç olan kurumsal web siteleri kurumsal çevresel vatandaşlık konusunda mesajların verilmesi için de önemli bir araçtır. Bu çerçevede Jun Yu, Kevin R. Coulson, Joyce X. Zhou, H. Joseph Wen ve Qiang Zhao $(2011,198)$, çevresel vatandaşlığ 12 kategori tanımlamışlar ve bunlar üzerinden kurumların web siteleri üzerinden kurumsal çevresel vatandaşlıği ele almışlardır. Bu kategoriler, enerji verimliliği, çevresel etkilerin en aza indirgenmesi, temiz ve yeşil enerji kaynakları, Kyoto protokolü/sera emisyonları, yasal uygunluk, ISO14000/çevre yönetim sistemleri, koruma, geri dönüşüm /atık azaltma, çevre eğitimi, enerji tasarrufu, enerji talebinin yönetimi/eksiklikler ve çevre ödülleridir.

Yapılan çalışmada, bu araştırmayı temel alarak, 2017 Fortune 500 Türkiye listesine girmiş ilk 50 şirketin kurumsal web sitelerinde kurumsal çevre vatandaşlıklarına dair mesajlar iletip iletmedikleri incelenmiştir. Bahsedilen şirketlerin web sitelerinin incelenmesi üzerinden yapılan bu çalışmada, kurumların 'çevresel vatandaşlık' çerçevesinde tanımlanan çalışmaları incelenmiş ve web siteleri üzerinden "çevresel vatandaş" mesajı verip vermediği ortaya konmuştur. Araştırma sonuçlarına göre; en yüksek sonuçlar, enerji verimliliği; çevresel etkilerin en aza indirgenmesi ve ISO 14000/çevre yönetim sistemleri kategorilerinde; en az görülenler ise enerji talebinin yönetimi/eksiklikler; çevre ödülleri; temiz ve yeşil enerji kaynakları kategorileri olmuştur. Kurumların çevreye dair yaptıkları çalışmalar ve çevre bilinci web siteleri bazında incelenmiş olup, kategorilerin olmaması kurumların çevresel vatandaşlı̆̆ına dair davranışları ölçmek için yeterli olmamakta, sadece web sitelerinde yer verip vermediklerine dair olan bilgiyi ölçmektedir.

Çalışmanın araştırma sonucunu göre Fortune 500'e giren ilk 50 şirket, kurumsal çevresel vatandaşlık kavramına dair mesajlarını web siteleri üzerinden paydaşlarına iletmektedirler. $\mathrm{Bu}$ şirketler çevresel vatandaşlığın paydaşlar tarafından önemsendiğini kavramış ve bu doğrultuda mesajlar ileterek, tutumlarını da davranışa dönüştüren eylemlerde bulunduklarını ortaya 
koymuşlardır. Bu kurumlar, kurumsal sosyal sorumluluk kapsamı içinde çevresel vatandaşlığın önemini anlamakta, bu konuya dair yapılan çalışmalarda yer almakta ve bunları da web siteleri aracılığıla duyurmaktadırlar. 


\section{Kaynakça}

Badarocco, C. H. (1998). The Transparent Corporation and Organized Community. Public Relations Review, 24(3), 265-272.

Banerjee, S. B. (2002). Corporate Environmentalism, The Construct and its Measurement. Journal of Business Review, Vol. 55, 177-191.

Bowen, H. R. (1953). Social Responsibilities of the Businessman. New York: Harper \&Row.

Carroll, A. B. (1979). A Three-Dimensional Conceptual Model of Corporate Social Performance", Academy of Management Review, Vol. 4 No. 4, 497-505.

Carroll, A. B. (1991). The Pyramid of Corporate Social Responsibility: Toward The Moral Management of Organizational Stakeholders. Business Horizons, 34(4), 39-48.

Carroll, A. B. (1998). The Four Faces of Corporate Citizenship, Business \& Society Review, Sep98, Issue 100/101, 1-7.

Chin, T. L., Yean, T. F., Yahya, K. K. (2017). Ability, Motivation, Opportunity Enhancing Human Resource Management and Corporate Environmental Citizenship: What's the Connection?.Global Business and Management Research: An International Journal Vol. 9, No. 1s (Special Issue 2017).

Crane, A., Matten, D., Moon, J. (2008). The Emergence of Corporate Citizenship: Historical Development and Alternative Perspectives, Ed: Andreas Georg Scherer and Guido Palazzo, Handbook of Research on Global Corporate Citizenship. USA: Edward Elgar Publishing Limited.

Engin, E., Akgöz, B. E. (2016). Belediyelerin Web Sitelerinin Diyalojik Iletişim Açısından Analizi. Atatürk Iletişim Dergisi(10), 91-110.

Eren, E. (2000). Stratejik Yönetim ve İsletme Politikası. İstanbul: Beta Yayınları, (5. Bs).

Ersel, H. (2006). 23 Kasım 2006 Referans Gazetesi, Milton Friedman ve Şirketlerin Sosyal Sorumluluğu, http://acikradyo.com.tr/arsiv-icerigi/milton-friedman-ve-sirketlerintoplumsal-sorumlulugu).

Gower, K. K., Cho, J. Y. (2001). Use Of The Internet Curcillum in The Public Relations Curriculum Journalism \& Mass Communication Educator, Summer, Vol. 56 Issue 2,.81-92.

Guth, D. W., Marsh, C. (2006). Public Relations : A Values-Driven Approach. USA: Pearson Education (3rd Edition).

Logan, D., Roy, D. and Regelbrugge, L. (1997). Global Corporate Citizenship - Rationale and Strategies. The Hitachi Foundation, Washington DC.

Mazurkiewicz, P. (2004). Corporate Environmental Responsibility: Is a Common CSR Framework Possible? Retrieved from http://www.sitesources.worldbank.org.

Nayyar, S., Sharma, R. (2016). Corporate Social Responsibility and Environment Protection. The Government: Research Journal of Political Science Vol. V, 1-15.

Nishitani, K., Jannah, N., Kaneko, S., Hardinsyahd. (2017). Does Corporate Environmental Performance Enhance Financial Performance? An Empirical Study of Indonesian Firms, Environmental Development, Vol 23, 10-21. 
Okay, A., Okay, A. (2005). Halkla İlişkiler Kavram, Strateji ve Uygulamaları. İstanbul: Der Yayınları. (2.Bs).

Özen, Ş., Küskü, F. (2009). Corporate Environmental Citizenship Variation in Developing Countries: An Institutional Framework, Journal of Business Ethics. 89, 297-313.

Pallant, J. (2007). SPSS Survival Manual: A Step by Step Guide to Data Analysis Using SPSS for Windows Bekshire England: Mc Graw Hill Open University Press (Third Edition).

Peltekoğlu, F. B. (2014). Halkla İlişkiler Nedir?. İstanbul: Beta Yayınları, (8.Bs).

Rondinelli, D.A., Berry, M.A., (2000). Environmental Citizenship in Multinational Corporations: Social Responsibility and Sustainable Development, European Management Journal Vol. 18, No. 1, 70-84.

Windsor, D. (2006). Corporate Social Responsibility: Three Key Approaches, Journal of Management Studies, 43:1, January, 93-114.

Young, D. (2001). Public Web Sites as a Component of Corporate Supplier Communication, Information Strategy: The Executive's Journal, 18-28.

Yu, J., Coulson, R.K., Zhou, X.J., Wen, H.J., Zhao, Q. (2011). Communicating Corporate Environmental Citizenship: An Examination of Fortune 500 Web Sites , Journal of Internet Commerce, Vol 10, 193-207. 